Article

\title{
The Potential for Improving Rice Yield and Nitrogen Use Efficiency in Smallholder Farmers: A Case Study of Jiangsu, China
}

\author{
Kailiu Xie ${ }^{1} \mathbb{1}$, Junjie Guo ${ }^{1}$, Katie Ward ${ }^{2}$, Gongwen Luo ${ }^{1}$, Qirong Shen ${ }^{1}$ and Shiwei Guo ${ }^{1, *}$ \\ 1 Jiangsu Provincial Key Lab of Solid Organic Waste Utilization, Jiangsu Collaborative Innovation Center for \\ Solid Organic Waste, Educational Ministry Engineering Center of Resource-saving fertilizers, \\ Nanjing Agricultural University, Nanjing 210095, China; 2015203028@njau.edu.cn (K.X.); \\ junjieguo@njau.edu.cn (J.G.); 2017203048@njau.edu.cn (G.L.); shenqirong@njau.edu.cn (Q.S.) \\ 2 School of Biology, University of Leeds, West Yorkshire LS7 4QH, UK; katieward1993@gmail.com \\ * Correspondence: sguo@njau.edu.cn; Tel.: +86-25-84396393
}

Received: 16 February 2020; Accepted: 17 March 2020; Published: 19 March 2020

check for updates

\begin{abstract}
Closing yield (YG) and nitrogen use efficiency (NUE) gaps amongst smallholder farmers are critical to ensuring food security and environmental sustainability. Here we report a comprehensive analysis of a data set derived from farm-surveys and previously published studies in a typical high $\mathrm{N}$ input area of China. Using scenario analysis, farmers from both sources were divided into four rice production levels to assess the YG and NUE of smallholder farmers. Farm surveys showed that rice yield and partial factor productivity of applied $\mathrm{N}\left(\mathrm{PFP}_{\mathrm{N}}\right)$ averaged $8273 \mathrm{~kg} \mathrm{ha}^{-1}$ and $23.1 \mathrm{~kg} \mathrm{~kg}^{-1}$ at regional-scale, with a potential increase of $21-43 \%$ and $33-52 \%$, respectively. A wide variation in yield and $\mathrm{PFP}_{\mathrm{N}}$ across different types of farmer was observed. Optimized $\mathrm{N}$ management significantly narrowed $\mathrm{YGs}$ by $3.7 \%$ and $\mathrm{PFP}_{\mathrm{N}}$ gap by $63.5 \%$ on average based on the published literature. Multiple factors, including excessive $\mathrm{N}$ rates, small rice planting area ( $0.33 \mathrm{ha})$, the aging (51 years old) and low education level (6 years of education) of the major labor force, can partly explain causes of yield and NUE gaps. These findings provide farm-based evidence that centralized management, good agronomy plus advances in knowledge and technologies are essential for future agricultural development.
\end{abstract}

Keywords: rice; yield gap; nitrogen use efficiency; smallholder

\section{Introduction}

Rice (Oryza sativa L.), the most consumed staple crop in the world, covers $29 \%$ of the global cereal area, and accounts for $31 \%$ of global crop production [1]. An increase in rice production of at least 35\% is required by 2033 to meet the food and energy demands of a growing population [2,3]. The size of yield gaps (YGs) varies around the world with yields achieving on average $20-80 \%$ of yield potential. YGs are especially large in developing countries where smallholder farming dominates the agricultural landscape [4-7]. Closing the YGs between farmers' actual and attainable yield is a well-established strategy to overcome the challenge of food security [8-10].

In order to attain high rice yields, farmers generally apply excessive $\mathrm{N}$ fertilizer, especially in some developing countries, e.g., China and India [11,12]. Nitrogen use efficiency (NUE), therefore, has received much attention around the world. The $\mathrm{N}$ fertilizer application rates of China and India are the highest in the world, accounting for $22.3 \%$ and $12.5 \%$ of global $\mathrm{N}$ consumption, respectively [1]. Despite the over-application of $\mathrm{N}$, however, crop yields remain below the attainable level leading to low NUE [13,14] and high environmental risks [15-17]. Therefore, the major challenge in rice farming amongst smallholder farmers is to overcome the overuse of $\mathrm{N}$ fertilizer and low NUE while reducing 
YGs $[18,19]$, which is essential for addressing the double challenges of food security while minimizing adverse environmental effects [20,21].

There are many biotic and abiotic factors that interact to limit yields and NUE, e.g., inappropriate crop management practices [7,22,23], poor soil fertility and weed infestation [24] and wrong sowing time [25], etc. Previous studies have shown that rice yield and NUE can be increased by new technologies and management activities adopted by farmers [26-29]. In sub-Saharan Africa (SSA) growing improved cultivars, adopting technologies that improve nutrient and water use efficiency and weed management could increase relative yield gains, e.g., improving weed management alone could increase relative yield gains by $91.6 \%$ [30]. An et al. [19] suggested that adopting best management practices, such as optimized $\mathrm{N}$ and water use and increasing rice transplanting density, could narrow YG and NUE gap by $38 \%$ and 39\%, respectively, within and between Chinese rice farming systems. Analysis of limiting factors would help improve our understanding of the causes of yield or NUE gaps and propose reasonable suggestions and measures.

As a leading country in rice-cultivation, China contributes to nearly $28 \%$ of the world's total rice production with $19 \%$ of the global harvested area [1]. Rice yield per hectare in China is currently $49.5 \%$ higher than the global mean [1]; however, $\mathrm{N}$ rate $\left(209 \mathrm{~kg} \mathrm{ha}^{-1}\right)$ is $90 \%$ higher than the global average [7], resulting in lower NUE [31,32]. Hence, achieving high yields with high NUE is urgently required in China. Here, we performed a comprehensive analysis by building a data set from farm surveys and previously published literature to estimate the potential for improving rice yield and NUE of smallholder farmers in Jiangsu province, China. Jiangsu is a major rice-producing region with a typically high $\mathrm{N}$-input. The objectives of this study were to: (i) assess rice YGs and NUE gaps of farmers in the Jiangsu region of China; (ii) quantify the potential of strategies designed to increase yield and NUE; and (iii) analyze limiting factors affecting yield and N-input.

\section{Materials and Methods}

\subsection{Site Description and Data Collection}

Jiangsu, the most developed economic and agricultural province in China, lies between east longitude $116^{\circ} 18^{\prime}-121^{\circ} 57^{\prime}$ and north latitude $30^{\circ} 45^{\prime}-35^{\circ} 20^{\prime}$. This area has a typical monsoon climate transitioning from a warm-temperate zone to a north subtropical zone. The mean annual temperature is $15.9^{\circ} \mathrm{C}$ and the mean annual precipitation varies from 781-1382 $\mathrm{mm}$ [33]. The properties of the top layer soil $(0-20 \mathrm{~cm})$ in Jiangsu are as follows: organic matter, $21.65-24.73 \mathrm{~g} \mathrm{~kg}^{-1}$; total N, $1.15-1.61 \mathrm{~g} \mathrm{~kg}^{-1}$; Olsen-P, 12.95-15.74 $\mathrm{mg} \mathrm{kg}^{-1}$; $\mathrm{NH}_{4} \mathrm{OAc}-\mathrm{K}, 89.51-141.11 \mathrm{mg} \mathrm{kg}^{-1}$; and $\mathrm{pH}, 6.54-7.46$ [34].

The data used in this study was obtained from two sources (Table S1). Farm surveys were conducted from 2008 to 2014 to evaluate the on-farm yield achieved by farmers. A total of 1505 samples were selected for analysis $(2008, \mathrm{n}=128 ; 2009, \mathrm{n}=434 ; 2010, \mathrm{n}=60 ; 2011, \mathrm{n}=301 ; 2012, \mathrm{n}=250 ; 2013$, $\mathrm{n}=90 ; 2014, \mathrm{n}=242$ ). Based on the data of from 2008 to 2012 in the early stage of our laboratory [34], combined with the later survey data and literature collective data, the analysis of yield and NUE gaps is carried out in this study. Households were selected randomly in Jiangsu, China. Interviews with farmers were conducted face-to-face. All of these in-house surveys were conducted by professional research staff. Questions were designed to capture information related to rice production, such as yield and fertilizer inputs, farmers' perceptions of the system and household characteristics including the age of the workforce, education level and farm size. In addition to farm surveys, we retrieved studies ( $n=186$ ) published electronically from 2000 to 2017 with regard to rice nitrogen management in Jiangsu, including farmers' fertilizer practices (FP) and optimized N management (OPT). We used data from these studies to establish a database that included information on improving both yield and NUE of rice crops. 


\subsection{Database Description}

\subsubsection{Scenario Analysis}

Considering the large variation in yield and $\mathrm{N}$ rate in Jiangsu area, farmers were allocated to one of four groups based on productivity and nitrogen use efficiency (NUE) in Figure 1: (i) high yield and high NUE (HYHE); (ii) low yield and high NUE (LYHE); (iii) high yield and low NUE (HYLE); and (iv) low yield and low NUE (LYLE). The criteria for categorizing farmers were determined according to the scenario analysis proposed by Cui et al. [35]. The production of rice is divided into four categories according to the average yield and $\mathrm{N}$ application rate.

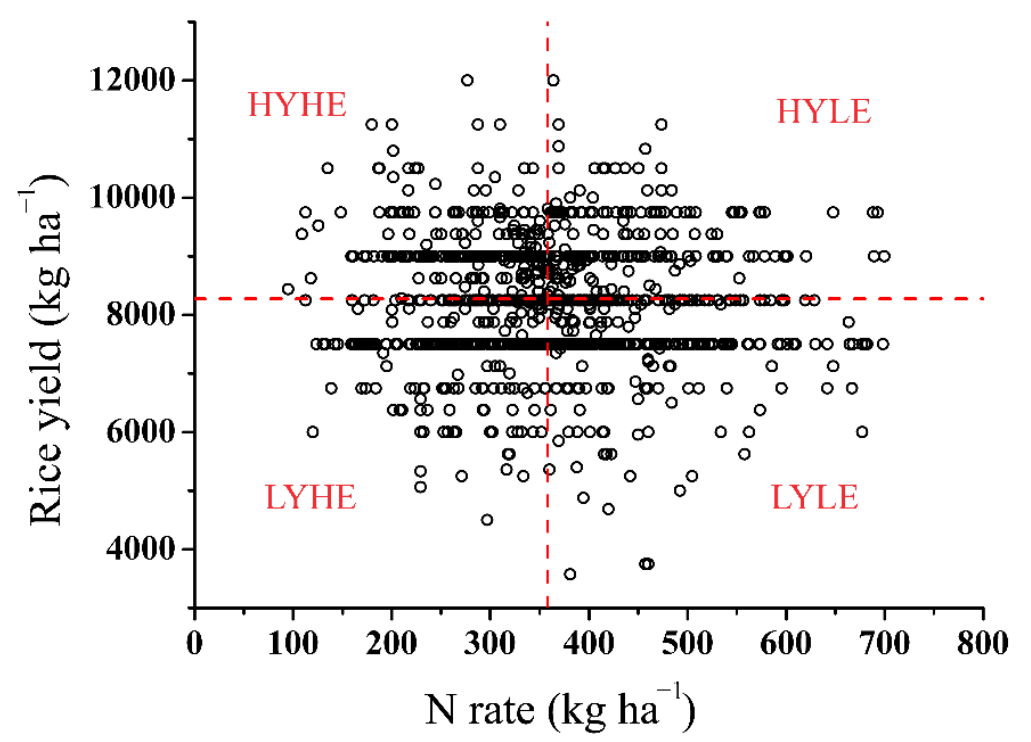

Figure 1. Criteria of four types (HYHE, HYLE, LYHE and LYLE) of farmers' productivity level. Black circles represent the distribution of actual farmers' yields in Jiangsu province. Data from farm surveys was conducted from 2008 to 2014 . The red dotted lines reflect the production of rice is divided into four categories according to the average yield and N application rate. HYHE, HYLE, LYHE and LYLE represent high yield and high $\mathrm{N}$ use efficiency (NUE), high yield and low NUE, low yield and high NUE, and low yield and low NUE, respectively.

\subsubsection{Potential Yield}

The highest recorded yield was taken from published data recorded by agronomists at the selected locations under the most favorable ecological conditions with extensive inputs, regardless of the economic costs and environmental risks [36,37]. The sites used to estimate yield potential and those with the highest recorded yields published in the literature were those with good ecological conditions and extensive inputs. Therefore, farmers may have great difficulty in attaining comparable yields and high-yield records do not reflect actual production in the region. In this study, highest recorded yields were extracted from the literature from 2008 to 2014 in Jiangsu province [38].

The experimental yield was collected from published field experiments, which were conducted by farmers using management practices recommended by local agronomists. These experiments are important because they reflect the response of yields to management practices when abiotic factors such as temperature and light are not limiting [39-41]. Economic costs and environmental risks were typically lower when compared with those in highest recorded yield [4]. In our study, experimental yield data was estimated from 2008 to 2014 and was derived from farmers using recommended management practices under conditions similar to those in most farmers' fields in terms of crop varieties, sowing dates, sowing density and irrigation [42].

An alternative but less common approach to estimating yield potential is to analyze the maximum yield (i.e., best farmers' yield) achieved among a sizable sample of farmers in a region of interest. 
Best farmers' yield refers to the level of production achieved by the farmers with higher yields among a large number of farmers, which is generally calculated according to the top $5-10 \%$ of yields achieved by the farmers $[4,39,43]$. Best farmers' yield is the actual yield achieved by farmers, which is limited by input costs and technical conditions. Therefore, best farmers' yield is usually lower than the highest recorded yield and can differ each season and in each area. In our study, the best farmers' yield is those achieving yields in the top $5 \%$, based on farm survey results.

\subsubsection{Yield Gaps Analysis}

To aid comparisons of different yield levels, three yield gaps were defined based on different measures of yield potential or attainable yields: highest recorded-based yield gap (YGR), experiment-based yield gap (YGE), and best farmers-based yield gap (YGF). Average farmers' yield was calculated from farm survey results. The three gaps were calculated:

$$
\begin{gathered}
\text { YGR }=\text { Highest recorded yield }- \text { Average farmers' yield } \\
\text { YGE }=\text { Experimental yield }- \text { Average farmers' yield } \\
\text { YGF }=\text { Best farmers' yield }- \text { Average farmers' yield }
\end{gathered}
$$

\subsubsection{Nitrogen Use Efficiency}

NUE can be defined as the yield produced per unit of $\mathrm{N}$ applied [44,45]. Here, we use the $\mathrm{N}$ partial factor productivity $\left(\mathrm{PFP}_{\mathrm{N}}, \mathrm{kg}\right.$ rice grain per $\mathrm{kg} \mathrm{N}$ applied) as the broadest measure of NUE because it integrates fertilizer input, inherent soil $\mathrm{N}$ supply capacity and the yield achieved [46] and is suitable for the analysis of survey data. We calculated the $\operatorname{PFP}_{\mathrm{N}}$ corresponding to potential yield. The NUE corresponding to potential yield is not necessarily the potential NUE. Empirical evidence suggests that yield and NUE gaps are partially independent, and both decreases and increases in efficiency gaps have been found in farming practice in current efforts to close yield gap [47]. Therefore, the definition of potential NUE in this study has certain limitations, and consideration should be given to whether the following conditions are met. Firstly, under the necessary conditions of high yield, a certain high NUE (at least above the regional average) has been achieved in the sample we selected. Besides, according to our research purpose and object, a typical high $\mathrm{N}$-input area, it should meet the requirements that decreasing the YG can also be accompanied by a narrowing of the NUE gap. Thus, we defined the attainable $\mathrm{PFP}_{\mathrm{N}}$ to be the ratio of the attainable potential yield (highest recorded yield, experimental yield and best farmers' yield) mentioned above to the synthetic $\mathrm{N}$ application rate accordingly. The $\mathrm{PFP}_{\mathrm{N}}$ gap refers to the difference between attainable $\mathrm{PFP}_{\mathrm{N}}$ and farmers ${ }^{\prime} \mathrm{PFP}_{\mathrm{N}}$. $\mathrm{PFP}_{\mathrm{N}}$ is calculated as follows:

$$
\operatorname{PFP}_{\mathrm{N}}=\frac{\text { Grain yield with } \mathrm{N} \text { application }}{\mathrm{N} \text { application rate }}
$$

\subsection{Statistical Analysis}

All figures were drawn using Origin 8.0 software (Origin Lab, Northampton, MA, USA). Statistical analyses were performed using SPSS 17.0 software (SPSS Inc., Chicago, IL, USA). Differences between mean values was determined by the least significant difference (LSD) test at the $p<0.05$ level, or independent sample $t$ test $\left(p<0.05^{*}, p<0.01^{* *}, p<0.001^{* *}\right)$.

\section{Results}

\subsection{Measures of Yield and Nitrogen Status Amongst Surveyed Farmers}

Based on survey results, rice yields achieved by farmers significantly increased from $8012 \mathrm{~kg} \mathrm{ha}^{-1}$ in 2008 to $8883 \mathrm{~kg} \mathrm{ha}^{-1}$ in 2014 (Figure 2 and Table S2). Grain yield and $\mathrm{PFP}_{\mathrm{N}}$ were $8273 \mathrm{~kg} \mathrm{ha}^{-1}$ 
and $23.1 \mathrm{~kg} \mathrm{~kg}^{-1}$ on average, respectively. $\mathrm{N}$ application rate averaged $358 \mathrm{~kg} \mathrm{ha}^{-1}$ and significantly increased by $15.8 \%$ from $329 \mathrm{~kg} \mathrm{ha}^{-1}$ in 2008 to $381 \mathrm{~kg} \mathrm{ha}^{-1}$ in 2014.
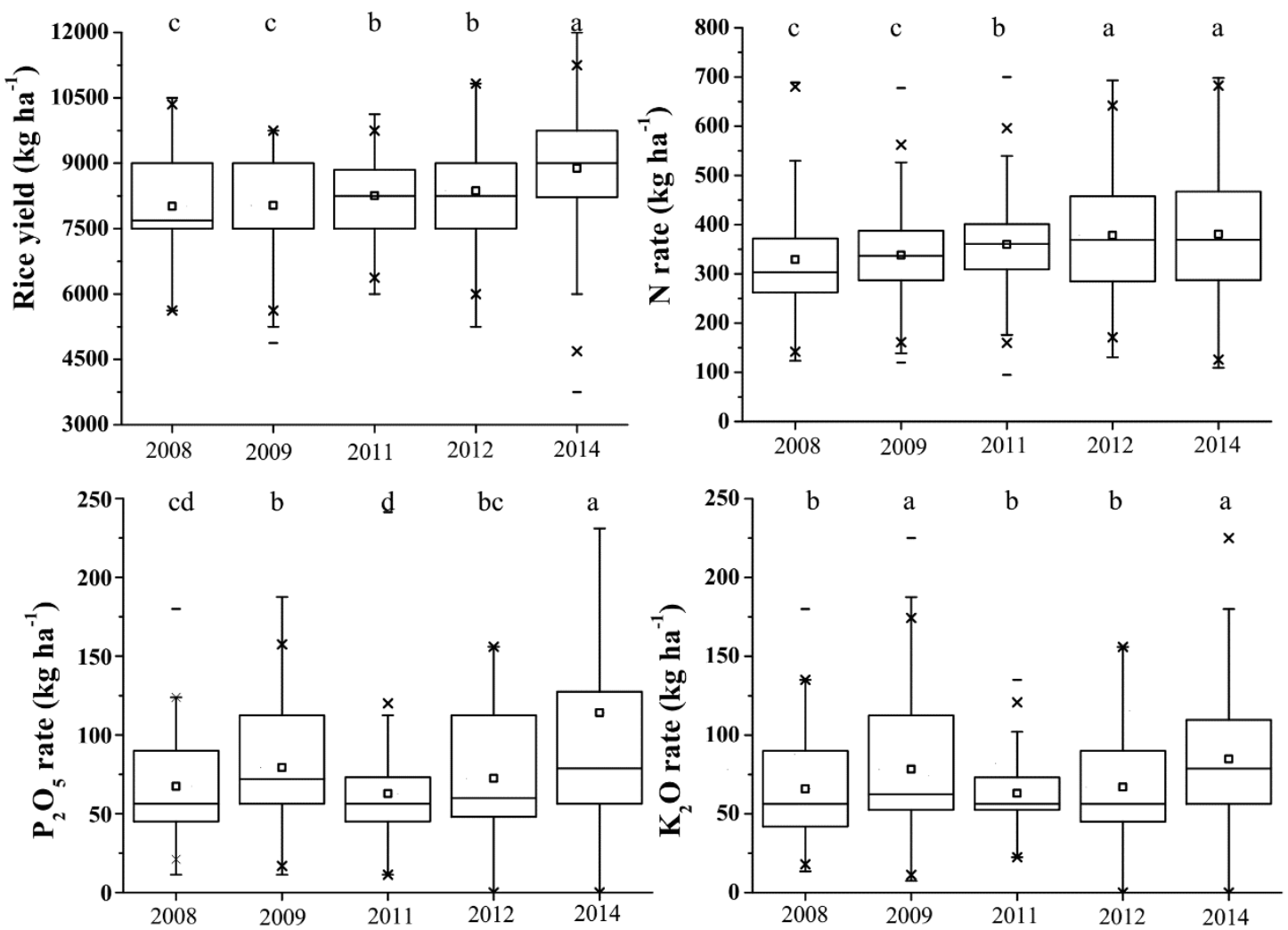

Figure 2. Descriptive statistics from farms surveys conducted in Jiangsu province, China, from 2008 to 2014 including rice yield and nitrogen $(\mathrm{N})$, phosphorus $\left(\mathrm{P}_{2} \mathrm{O}_{5}\right)$ and potassium $\left(\mathrm{K}_{2} \mathrm{O}\right)$ application rates $(2008, \mathrm{n}=128 ; 2009, \mathrm{n}=434 ; 2011, \mathrm{n}=301 ; 2012, \mathrm{n}=250 ; 2014, \mathrm{n}=242)$. Data in 2010 and 2013 are not presented due to low sample size. Different letters represent statistically significant differences in these indicators among years at $p<0.05$ level. Symbols: horizontal lines and squares within boxes indicate median and means, respectively; lower and upper boundary of boxes, 25th and 75th percentiles; lower and upper error bars, 10th and 90th percentiles; crosses, 1th and 99th percentiles; short-lines, maximum and minimum values.

The criteria used to allocate farmers to different groups are presented in Table 1 and the distribution of farmers across groups is shown in Figure 1. 53.7\% of farmers surveyed were classed as high NUE farmers (Table 1). $23.1 \%$ of farmers (HYHE) applied $286 \mathrm{~kg} \mathrm{~N} \mathrm{ha}^{-1}$, achieving yields of $9231 \mathrm{~kg} \mathrm{ha}^{-1}$ and $\mathrm{PFP}_{\mathrm{N}}$ of $34.0 \mathrm{~kg} \mathrm{~kg}^{-1}$. LYHE farmers, $30.6 \%$ of farmers surveyed, applied the same $\mathrm{N}$ rates $\left(289 \mathrm{~kg} \mathrm{ha}^{-1}\right)$ as HYHE famers, but their yield $\left(7537 \mathrm{~kg} \mathrm{ha}^{-1}\right)$ and $\mathrm{PFP}_{\mathrm{N}}\left(27.2 \mathrm{~kg} \mathrm{~kg}^{-1}\right)$ was significantly lower than HYHE farmers. $46.3 \%$ of farmers fell into the low NUE categories. HYLE and LYLE farmers applied approximately 1.5 times more $\mathrm{N}$ rate than HYHE and HYLE farmers to attain the same respective yields. HYLE farmers (19.0\% of those surveyed) applied $432 \mathrm{~kg} \mathrm{~N}^{-1}$ and achieved yields of $9310 \mathrm{~kg} \mathrm{ha}^{-1}$ with $\mathrm{PFP}_{\mathrm{N}}$ of $22.0 \mathrm{~kg} \mathrm{~kg}^{-1}$. Compared to farmers in other groups, LYLE farmers applied the highest $\mathrm{N}$ rate $\left(446 \mathrm{~kg} \mathrm{ha}^{-1}\right)$ but attained the lowest yields and $\mathrm{PFP}_{\mathrm{N}}$ of $7568 \mathrm{~kg} \mathrm{ha}^{-1}$ and $17.4 \mathrm{~kg} \mathrm{~kg}^{-1}$, respectively. 
Table 1. Rice yield, $\mathrm{N}$ rate and partial factor productivity of applied $\mathrm{N}\left(\mathrm{PFP}_{\mathrm{N}}\right)$ of farmers grouped according to production level and nitrogen use efficiency.

\begin{tabular}{|c|c|c|c|c|c|c|}
\hline $\begin{array}{c}\text { Farmers' }^{\prime} \\
\text { Production Level }^{\text {a }}\end{array}$ & $\begin{array}{l}\text { N Range } \\
\left(k^{b} \text { ha }^{-1}\right)\end{array}$ & $\begin{array}{l}\text { Yield Range } \\
\text { c }\left(k^{\prime} h^{-1}\right)\end{array}$ & $\begin{array}{c}\text { Yield } \\
\left(\mathrm{kg} \mathrm{ha}^{-1}\right)\end{array}$ & $\begin{array}{l}\text { N Rate } \\
\left(\mathrm{kg} \mathrm{ha}^{-1}\right)\end{array}$ & $\begin{array}{c}\mathrm{PFP}_{\mathrm{N}}(\mathrm{kg} \\
\left.\mathrm{kg}^{-1}\right)\end{array}$ & $\begin{array}{l}\text { Percentage of } \\
\text { Farmers }(\%)\end{array}$ \\
\hline HYHE & $<358$ & $>8273$ & 9231a & $286 c$ & $34.0 \mathrm{a}$ & 23.1 \\
\hline LYHE & $<358$ & $<8273$ & $7537 b$ & $289 \mathrm{c}$ & $27.2 b$ & 30.6 \\
\hline HYLE & $>358$ & $>8273$ & 9310a & $432 b$ & $22.0 \mathrm{c}$ & 19.0 \\
\hline LYLE & $>358$ & $<8273$ & $7568 b$ & $446 a$ & $17.4 \mathrm{~d}$ & 27.3 \\
\hline
\end{tabular}

${ }^{a}$ HYHE, LYHE, HYLE and LYLE represent high yield and high N use efficiency (NUE), low yield and high NUE, high yield and low NUE, and low yield and low NUE, respectively. ${ }^{\mathrm{b}}$ and ${ }^{\mathrm{c}}$ Criteria for categorizing farmers based on the average grain yield and $\mathrm{N}$ rate of farmers. The same criteria were used to group surveyed farmers and data from published literature. Different letters following the values in the same column indicate a statistically significant difference between farmers groups at $p<0.05$ level.

\subsection{Assessing Yield Gaps and Nitrogen Use Efficiency Gaps}

Three reference levels for yield and NUE were used to estimate yield gaps and NUE gaps (Table 2): (i) highest recorded yield and $\operatorname{PFP}_{\mathrm{N}}\left(\mathrm{Gap}_{\mathrm{H}}\right)$; (ii) experimental yield and $\operatorname{PFP}_{\mathrm{N}}\left(\mathrm{Gap}_{\mathrm{E}}\right.$ ); and (iii) best farmers' yield and $\mathrm{PFP}_{\mathrm{N}}\left(\mathrm{Gap}_{\mathrm{B}}\right)$. The yield gaps between average farmers' yield in Jiangsu and highest recorded yield, experimental yield and best farmers' yield were 6267, 4437 and $2170 \mathrm{~kg} \mathrm{ha}^{-1}$, respectively. On average farmers achieved $57 \%$ of highest recorded yield, $65 \%$ of experimental yield and $79 \%$ of best farmers' yield. 
Table 2. Actual yield, yield potential and yield and partial factor productivity of applied $\mathrm{N}\left(\mathrm{PFP}_{\mathrm{N}}\right)$ gaps amongst farmers categorized based on production level and nitrogen use efficiency.

\begin{tabular}{|c|c|c|c|c|c|c|}
\hline & & \multicolumn{4}{|c|}{ Farmers' Production Level $^{\text {a }}$} & \multirow{2}{*}{ Jiangsu-Average } \\
\hline & & HYHE & LYHE & HYLE & LYLE & \\
\hline \multirow{4}{*}{ Yields $\left(\mathrm{kg} \mathrm{ha}^{-1}\right)$ and $\operatorname{PFP}_{\mathrm{N}}\left(\mathrm{kg} \mathrm{kg}^{-1}\right)$} & Average farmers' yield $\left(\mathrm{PFP}_{\mathrm{N}}\right)$ & $9231(34.0)$ & $7537(27.2)$ & $9310(22.0)$ & $7568(17.4)$ & $8273(23.1)$ \\
\hline & Best farmers' yield $\left(\mathrm{PFP}_{\mathrm{N}}\right)$ & $10443(34.6)$ & $10443(34.6)$ & $10443(34.6)$ & $10443(34.6)$ & $10443(34.6)$ \\
\hline & Experimental yield $\left(\mathrm{PFP}_{\mathrm{N}}\right)$ & $12710(47.1)$ & $12710(47.1)$ & $12710(47.1)$ & $12710(47.1)$ & $12710(47.1)$ \\
\hline & Highest recorded yield $\left(\mathrm{PFP}_{\mathrm{N}}\right)$ & $14540(48.5)$ & $14540(48.5)$ & $14540(48.5)$ & $14540(48.5)$ & $14540(48.5)$ \\
\hline \multirow{3}{*}{ Yield gap $\left(\mathrm{kg} \mathrm{ha}^{-1}\right)$ and $\operatorname{PFP}_{\mathrm{N}}$ gap $\left(\mathrm{kg} \mathrm{kg}^{-1}\right)$} & Gap $_{F}$ & $1212(0.6)$ & $2906(7.4)$ & $1133(12.6)$ & 2875 (17.2) & $2170(11.5)$ \\
\hline & Gap $_{\mathrm{E}}$ & 3479 (13.1) & $5173(19.9)$ & $3400(25.1)$ & $5142(29.7)$ & $4437(24.0)$ \\
\hline & Gap $_{R}$ & $5309(14.5)$ & $7003(23.1)$ & $5230(26.5)$ & $6972(31.1)$ & $6267(25.4)$ \\
\hline \multirow{3}{*}{ Average yield or $\mathrm{PFP}_{\mathrm{N}}$ as $\%$ of } & Best farmers' yield $\left(\mathrm{PFP}_{\mathrm{N}}\right)$ & $88(98)$ & $72(79)$ & $89(64)$ & $72(50)$ & $79(67)$ \\
\hline & Experimental yield $\left(\mathrm{PFP}_{\mathrm{N}}\right)$ & $73(72)$ & $59(58)$ & $73(47)$ & $60(37)$ & $65(49)$ \\
\hline & Highest recorded yield $\left(\mathrm{PFP}_{\mathrm{N}}\right)$ & $63(70)$ & $52(56)$ & $64(45)$ & $52(36)$ & $57(48)$ \\
\hline
\end{tabular}

${ }^{a}$ HYHE, LYHE, HYLE and LYLE represent high yield and high N use efficiency (NUE), low yield and high NUE, high yield and low NUE, and low yield and low NUE, respectively. Gap $\mathrm{F}$, $\mathrm{Gap}_{E}, \mathrm{Gap}_{\mathrm{R}}$ represent yield gap or PFP $\mathrm{N}_{\mathrm{N}}$ gap between best farmers', experimental and highest recorded yield and average farmers' yield, respectively. The values outside and inside parentheses indicate yield and $\mathrm{PFP}_{\mathrm{N}}$, respectively. Best farmers' yield was the yield achieved by farmers in the 95th percentile. Average and best farmers' yields were calculated from farm surveys. Highest recorded yield was extracted from studies conducted by agronomists, under the most favorable ecological conditions and extensive inputs [38]. Experiment yield was obtained from experiments conducted by farmers using management practices recommended by local agronomists [42]. 
We separated farmers' rice production levels into two categories, high yield (HYHE and HYLE) and low yield (LYHE and LYLE) (Table 1). High yield farmers reached nearly $89 \%$ of best farmers' yield with a $1133-1212 \mathrm{~kg} \mathrm{ha}^{-1}$ gap. Low yield farmers achieved $72 \%$ of best farmers' yield with a $2875-2906 \mathrm{~kg} \mathrm{ha}^{-1}$ gap. High yield and low yield farmers attained approximately $73 \%$ and $60 \%$ of experimental yield, respectively, and corresponding gaps were $3400-3479$ and $5142-5173 \mathrm{~kg} \mathrm{ha}^{-1}$, respectively. The gaps between high yield farmers' and highest recorded yield varied from 5230 to $5309 \mathrm{~kg} \mathrm{ha}^{-1}$, which corresponds to $64 \%$ of highest recorded yield. Low yielding farmers achieved $52 \%$ of highest recorded yield with yield gaps of $6972-7003 \mathrm{~kg} \mathrm{ha}^{-1}$.

According to NUE level, farmers were separated into two categories, high NUE (HYHE and LYHE) and low NUE (HYLE and LYLE) (Table 1). The corresponding PFP $_{\mathrm{N}}$ of best farmers, experiment and highest recorded yield was 34.6, 47.1 and $48.5 \mathrm{~kg} \mathrm{~kg}^{-1}$, respectively. There are wide NUE gaps between average farmers' ${ }^{\prime} P_{N}$ in Jiangsu and potential $P_{F P}$ ranging from 11.5 to $25.4 \mathrm{~kg} \mathrm{~kg}^{-1}$. On average farmers achieved $48-67 \%$ of potential $\mathrm{PFP}_{\mathrm{N}}$. Results showed a trend in $\mathrm{PFP}_{\mathrm{N}}$ of $\mathrm{HYHE}>\mathrm{LYHE}>$ HYLE > LYLE (Table 2). The PFP ${ }_{\mathrm{N}}$ of HYHE and LYHE were $98 \%$ and $79 \%$ of the $\mathrm{PFP}_{\mathrm{N}}$ achieved by the best farmers, respectively. The NUE gaps between high NUE farmers' and experiment-yield' PFP $_{\mathrm{N}}$ were $13.1-19.9 \mathrm{~kg} \mathrm{~kg}^{-1}$. High NUE farmers achieved $56-70 \%$ of the $\mathrm{PFP}_{\mathrm{N}}$ of highest recorded yield. Compared to the three potential $\mathrm{PFP}_{\mathrm{N}}$, low NUE farmers achieved $\mathrm{PFP}_{\mathrm{N}}$ of $36-64 \%$, which corresponds to $\mathrm{PFP}_{\mathrm{N}}$ gaps of $12.6-31.1 \mathrm{~kg} \mathrm{~kg}^{-1}$.

\subsection{Closing Yield Gaps and Increasing NUE}

Data from published literature were divided using the same classification and production levels as farm surveys (HYHE, HYLE, LYHE and LYLE). HYLE and LYLE farmers were grouped together due to a low number of published examples. The average $\mathrm{N}$ application rate, yield and $\mathrm{PFP}_{\mathrm{N}}$ under conventional practice (FP) and optimized $\mathrm{N}$ management (OPT) were calculated for each farmer group (Table 3). HYHE farmers correspond to FP1 and OPT1. LYHE farmers correspond to FP2 and OPT2. HYLE and LYLE farmers are grouped together and correspond to FP3 and OPT3. OPT1, OPT2 and OPT3 are achieved by reducing $\mathrm{N}$ application rates, as outlined in this study, and through other comprehensive management measures (data not shown). Based on our analysis of statistics in published literature, OPT significantly reduced $\mathrm{N}$ fertilizer by $32.5 \%$ and increased grain yield by $3.7 \%$ when compared with FP (Table 3). Moreover, $\mathrm{PFP}_{\mathrm{N}}$ under OPT was significantly increased by $63.5 \%$ (Table 3).

Table 3. Average $\mathrm{N}$ rate, rice yield and partial factor of applied $\mathrm{N}\left(\mathrm{PFP}_{\mathrm{N}}\right)$ under conventional (FP) and optimized $\mathrm{N}$ management (OPT) of farmers categorized according to productivity and nitrogen use efficiency, based on data reported in the literature.

\begin{tabular}{|c|c|c|c|c|c|c|c|}
\hline \multirow{2}{*}{ Farmers' Production Level a } & \multicolumn{2}{|c|}{$\begin{array}{l}\text { N Rate } \\
\left(\mathrm{kg} \mathrm{ha}^{-1}\right)\end{array}$} & \multicolumn{2}{|c|}{$\begin{array}{c}\text { Yield } \\
\left(\mathrm{kg} \mathrm{ha}^{-1}\right)\end{array}$} & \multicolumn{2}{|c|}{$\begin{array}{c}\operatorname{PFP}_{N}{ }^{c} \\
\left(k k^{-1}\right)\end{array}$} & \multirow{2}{*}{$\begin{array}{c}\text { Sample Size } \\
\text { (n) }\end{array}$} \\
\hline & FP & OPT & FP & OPT & FP & OPT & \\
\hline HYHE & 289.8 & $192.0^{* * *}$ & 8961 & $9194 *$ & 31.1 & $52.5^{* * *}$ & 114 \\
\hline LYHE & 282.3 & $196.4^{* * *}$ & 7455 & $8045^{* * *}$ & 27.4 & $42.6^{* * *}$ & 64 \\
\hline HYLE, LYLE ${ }^{b}$ & 370.8 & $256.5^{* *}$ & 9903 & 9279 & 26.9 & $36.9^{* * *}$ & 8 \\
\hline Total & 290.7 & $196.3^{* * *}$ & 8484 & $8802 * *$ & 29.6 & $48.4^{* * *}$ & 186 \\
\hline
\end{tabular}

${ }^{a}$ HYHE, LYHE, HYLE and LYLE represent high yield and high $\mathrm{N}$ use efficiency (NUE), low yield and high NUE, high yield and low NUE, and low yield and low NUE, respectively. Nitrogen $(\mathrm{N})$ and rice yield data in published studies were used to categorize farmers according to the same criteria used for surveyed farmers. ${ }^{b}$ HYLE and LYLE farmers were grouped due to a low sample size. ${ }^{c} \mathrm{PFP}_{\mathrm{N}}$ has not been reported in part literatures, so we calculated the corresponding $\mathrm{PFP}_{\mathrm{N}}$ based on yield and $\mathrm{N}$ rate. The $\mathrm{PFP}_{\mathrm{N}}$ in the table is the average of all samples. The asterisk represents the significant difference of each index between FP and OPT. ${ }^{* * *}$ represents statistical significance at $p<0.001,{ }^{* *}$ represents statistical significance at $p<0.01$, and ${ }^{*}$ represents statistical significance at $p<0.05$.

To simplify the goal of high yield and high NUE for farmers, we divided the methods for increasing yield and NUE into two steps: (i) optimized fertilization from FP to OPT for each farmer type; and (ii) 
closing gaps among OPTs of farmer types, ultimately achieving OPT1 (the HYHE types) (Table 3 and Figure 3). HYHE (FP1) farmers could significantly increase their yield and $\mathrm{PFP}_{\mathrm{N}}$ by $2.6 \%$ and $68.8 \%$, respectively, by adopting OPT1 (Table 3). N application rate decreased by 33.7\% following the transition from FP1 to OPT1, which was achieved by reducing the amount of $\mathrm{N}$ applied at basal, tiller and spike growth stages by $41.0 \%, 40.2 \%$ and $9.8 \%$, respectively, combined with the use of organic fertilizers (Figure 3d). For LYHE farmers (FP2), optimized N management (OPT2) significantly increased rice yield and $\mathrm{PFP}_{\mathrm{N}}$ by $7.9 \%$ and $55.7 \%$, respectively. This was achieved through decreasing basal $(36.2 \%)$, tiller (39.9\%), and spike fertilizer N rates (15.7\%). Before OPT3, farmers in FP3 achieved average yields of $9903 \mathrm{~kg} \mathrm{ha}^{-1}$ but the $\mathrm{N}$ application rate was $370.8 \mathrm{~kg} \mathrm{ha}^{-1}$ which is $28.0 \%$ higher than FP1 (Table 3). Compared with $\mathrm{FP} 3, \mathrm{PFP}_{\mathrm{N}}$ in OPT3 was significantly increased by $37.2 \%$. Yield was reduced by $6.3 \%$ between FP3 and OPT3, although the difference was not statistically significant. The increased $\mathrm{PFP}_{\mathrm{N}}$ following OPT3 resulted directly from a $30.8 \%$ decrease in the $\mathrm{N}$ application rate, from $370.8 \mathrm{~kg} \mathrm{ha}^{-1}$ (FP3) to $256.5 \mathrm{~kg} \mathrm{ha}^{-1}$ (OPT3). To realize OPT3, basal, tiller and spike fertilizer rates in FP3 were decreased by $24.3 \%, 38.2 \%$ and $32.5 \%$, respectively.

There was a $14.3 \%$ increase in rice yield and a $23.2 \%$ increase in $\mathrm{PFP}_{\mathrm{N}}$ from OPT2 to OPT1 (Figure 3). Converting from OPT3 to OPT1 could increase PFP $_{N}$ by $42.3 \%$. Converting from OPT3 to OPT2 could increase $\mathrm{PFP}_{\mathrm{N}}$ by $15.5 \%$ and decrease yield by $13.3 \%$. 


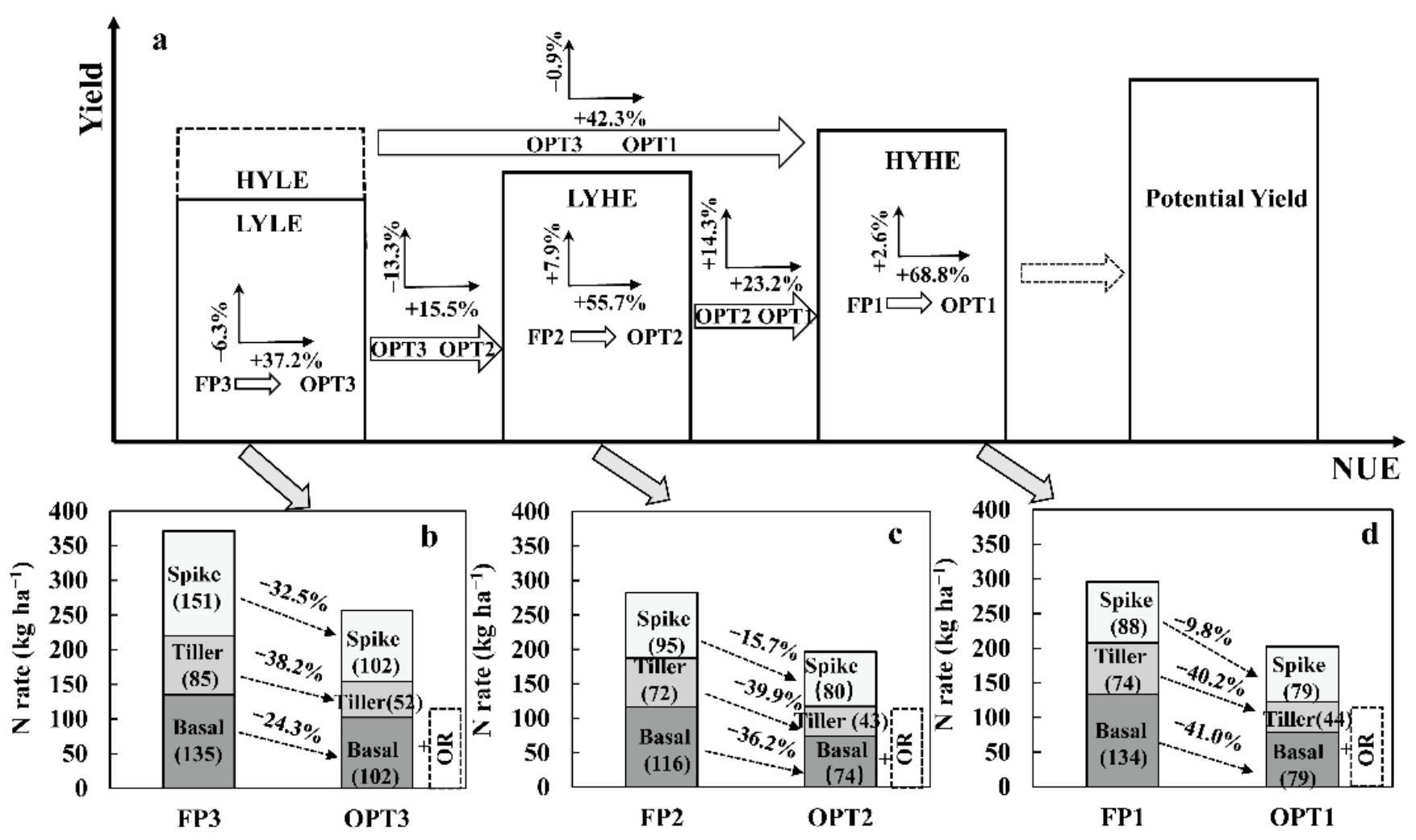

Figure 3. Schematic diagram of the response of rice yield and nitrogen use efficiency (NUE) to optimized N management for four categories of farmers. (a) Axes within boxes represent the change in NUE ( $x$-axis) and yield (y-axis) when farmers of each type transition from current practices (FP) to optimized management (OPT). Axes above arrows between boxes represent the change in NUE and yield when farmers transition within OPTs. (b-d) show N application rates at basal, tiller and spike growth stages for current and optimized practices. Numbers above dotted arrows represent the percentage decrease in N application rate under OPT management at different fertilizer stages, compared with FP. The dashed box 'OR' represents the addition of organic fertilizers. Data derived from studies published electronically from 2000 to 2017 


\section{Discussion}

\subsection{Yield Gaps and Nitrogen Use Efficiency Gaps}

Data from farm surveys showed that long-term actual yields averaged $8273 \mathrm{~kg} \mathrm{ha}^{-1}$ and significantly increased over time (Figure 2). Previous studies reported that farmers' rice yield was $7000 \mathrm{~kg} \mathrm{ha}^{-1}$ in China [7] and $8112 \mathrm{~kg} \mathrm{ha}^{-1}$ in the USA [1]. These results showed that the farmers in this area have achieved relatively high yields as a whole. However, only $57-79 \%$ of yield potential was achieved in farmers' fields (Table 2). High-yielding farmers (HYHE and HYLE) and low-yielding farmers (LYLE and HYLE) reached $63-89 \%$ and $52-72 \%$ of potential yield, respectively (Table 2), suggesting that the YGs across farmers types are subject to large variability. These YGs are within the range of values of Asian rice farmers reported by [4].

Grassini et al. [48] believed that China's rice production has reached or exceeded $80 \%$ of production potential, thus it is hard to increase yield without incurring further economic cost and technical difficulties. However, some scholars argued that there is the potential to reduce $\mathrm{N}$ use and increase grain yield by rational management techniques [26,34]. For example, Fan et al. [49] showed that compared with farmers' practice, improved crop management can increase rice yield of $20 \%$ with $\mathrm{N}$ fertilizer savings of $18 \%$. Chen et al. [7] reported that by adopting comprehensive soil and crop management, the output of farmers' rice increased by $21 \%$ and $\mathrm{N}$ rate decreased by $22 \%$. Based on our survey results, rice yield of HYHE farmers was $22.5 \%$ higher than LYHE despite equal $\mathrm{N}$ rates, and was $22.0 \%$ higher than LYLE with a $35.9 \%$ reduction in $\mathrm{N}$ inputs (Table 1). Those findings suggest that although farmers achieved high rice yields, there is still the potential to close yield gaps while decreasing $\mathrm{N}$ application rates.

Farmers in China usually over-apply synthetic $\mathrm{N}$ fertilizer to maximize grain yield, resulting in a steep decline in NUE [50,51]. In the typical N-overuse areas in China, the $\mathrm{PFP}_{\mathrm{N}}$ of surveyed farmers averaged $48-67 \%$ of potential $\mathrm{PFP}_{\mathrm{N}}$ (Table 2). There was wide variation in $\mathrm{PFP}_{\mathrm{N}}$ gaps across different farmer' types ranging from 0.6 to $31.1 \mathrm{~kg} \mathrm{~kg}^{-1}$ with $36-98 \%$ of potential $\mathrm{PFP}_{\mathrm{N}}$. Farmers' $\mathrm{PFP}_{\mathrm{N}}$ in this study averaged $23.1 \mathrm{~kg} \mathrm{ha}{ }^{-1}$, which were lower than farmers' $\mathrm{PFP}_{\mathrm{N}}$ of $41.1 \mathrm{~kg} \mathrm{~kg}^{-1}$ of irrigated rice reported previously on a national-scale in China [29]. $\mathrm{PFP}_{\mathrm{N}}$ values of $50 \mathrm{~kg} \mathrm{~kg}^{-1}$ and above are generally considered to be achievable with good management $[52,53]$. These results suggest that there is further potential for increasing rice yields and $\mathrm{PFP}_{\mathrm{N}}$ simultaneously for smallholder in $\mathrm{N}$-overuse areas.

The analysis of YG is necessary to determine rice yield gains resulting from the use of improved technologies, and how technical interventions should be adopted [30]. Experimental and best farmers' yields are more appropriate measures for calculating bridgeable yield gaps than highest recorded yield because these production levels are both attainable by farmers. Narrowing best farmers-based yield gap (YGF) is often considered the first step $[8,40]$. Amongst different farmer' types, grain yield and PFP $_{\mathrm{N}}$ of HYHE-farmers surveyed achieved $88 \%$ and $98 \%$ of best farmers' level, respectively (Table 2). Given the small gaps of yield and NUE between HYHE farmers and best farmers, HYHE can be considered as the first goal for other types of farmers. Narrowing experiment-based yield gap (YGE) seems to be an efficient tool to increase grain yield in the short term, due to the similarities between experimental and farmers' field conditions [54,55]. In order to determine strategies to increase rice productivity on farmers' fields, we used published data from field trials to study the YGs and $\mathrm{PFP}_{\mathrm{N}}$ gaps between farmers' fertilizer practices (FP) and optimized N management (OPT).

\subsection{Narrowing Gaps of Yield and NUE}

Generally, yield and $\mathrm{N}$ rates in a region are highly variable. In China, the amount of $\mathrm{N}$ fertilizer applied across the major rice production provinces ranges from 50 to $400 \mathrm{~kg} \mathrm{ha}^{-1}$, and there is no correlation with yield [28,56]. Considering the large variation in yield and $\mathrm{N}$ rate, it is beneficial for each type of farmers to separately optimize $\mathrm{N}$ fertilizer rates in order to achieve HYHE (Table 3). Based on the analysis of published data, transitioning from FP to OPT for each type of farmer could 
largely increase the $\mathrm{PFP}_{\mathrm{N}}$ of 37.2-68.8\% with a significant increase or no significant change in grain yield, suggesting that optimized $\mathrm{N}$ management can significantly improve NUE by stabilizing or further improving yield. The exception was low-NUE farmers (FP3); yields decreased by $6.3 \%$ between FP3 and OPT3, although this was not statistically significant. The decreasing trend in yield may be due to the reduced $\mathrm{N}$ use by these farmers from excessive levels of over $350 \mathrm{~kg} \mathrm{ha}^{-1}$. Previous studies have shown that directly reducing chemical $\mathrm{N}$ fertilizer rates leads to a decline in yield [57-59]. When increases in yield occurred, they could largely be attributed to greater plant $\mathrm{N}$ uptake and higher NUE, because optimized $\mathrm{N}$ management generally result in a better synchronization between crop $\mathrm{N}$ demand and $\mathrm{N}$ supply throughout the growing season $[27,50,60]$. Increases in rice yields in the future are likely to be driven by increasing NUE [18]. These results provide further evidence that the quantities of $\mathrm{N}$ fertilizer applied can be reduced with no detrimental effect on yield [61,62], and high yields and high NUE can be achieved simultaneously in high N-input area.

The potential increase in yield and NUE within different OPTs was also analyzed (Figure 3). Results showed that the potential to increase NUE was relatively large (15.5-42.3\%). However, the potential increase in yield depended on the type of OPT (-13.3-14.3\%). It should be noted that the yield and efficiency of FP and OPT vary greatly in this region due to the differences in soil, fertility and other natural conditions across different subregions. Therefore, the level of OPTs might be limited by the difference of agricultural technology or sub-regional restrictions. The aim of the current study was to gain an understanding of the general direction of $\mathrm{N}$ fertilizer optimization at a regional-scale. However, sub-regional optimization strategies and optimization within OPTs should be adjusted or analyzed to reflect the actual situation on a small-scale. In addition to the appropriate rate of $\mathrm{N}$ fertilizer mentioned in this study, agronomic practices, climate, inherent soil and other limiting factors should be considered comprehensively when optimizing rice yield and NUE [63-66].

\subsection{Analysis of Limiting Factors}

Based on farmer interviews and field observations, there were a number of factors limiting yield and NUE in farmers' fields. In the current study, the average rates of $\mathrm{N}, \mathrm{P}_{2} \mathrm{O}_{5}$ and $\mathrm{K}_{2} \mathrm{O}$ of surveyed farmers were $358,80.6$ and $73.0 \mathrm{~kg} \mathrm{ha}^{-1}$, respectively (Table 4). To achieve high rice yield $\left(>9000 \mathrm{~kg} \mathrm{ha}^{-1}\right.$ ), the recommended fertilizer rates in this region are $180-270 \mathrm{~kg} \mathrm{~N}^{-1}, 60-90 \mathrm{~kg} \mathrm{P}_{2} \mathrm{O}_{5}$ $\mathrm{ha}^{-1}$ and $75-120 \mathrm{~kg} \mathrm{~K}_{2} \mathrm{O} \mathrm{ha}^{-1}$ [67]. Results of surveys showed that $\mathrm{N}$ rates in LYLE were significantly higher and $\mathrm{K}_{2} \mathrm{O}$ significantly lower than other types of famers, and fell outside of the recommended fertilizer application rates, suggesting that excessive $\mathrm{N}$ input and relatively insufficient $\mathrm{K}_{2} \mathrm{O}$ rates or unbalanced fertilization might affect yield amongst LYLE farmers. Zhen et al. [68] reported that part of crop YGs can be explained by unbalanced fertilizer applications.

Previous studies suggested that a small farm size and smallholder management are considered key causes of low agricultural productivity worldwide [69]. In China, smallholder farms account for $98 \%$ of the total farm area with 0.43 ha of average size per household [70]. In this study, the rice planting area per household averaged 0.33 ha and $60 \%$ of farmers have $<0.3$ ha planting area (Table 4 and Table S3). At such a small scale, many technological innovations, pathways of knowledge transfer to farmers and modern management practices are less effective due to the high fixed costs of adoption [71]. Farm size limits farmers' agricultural income, which affects the enthusiasm of farmers engaged in rice production and leads to lower agricultural labor productivity [69,72], resulting in lower farm productivity [68]. We also found that that the planting area of farmers with lower $\mathrm{N}$ input was significantly higher than that of farmers with higher $\mathrm{N}$ input, indicating that the $\mathrm{N}$ application rates decrease with planting area. Similar to the results of Wu et al. [72] that a $0.3 \%$ decrease in fertilizer use per hectare with every $1 \%$ increase in farm size. Therefore, small planting area can explain part of causes of yield or efficiency gaps. 
Table 4. Limiting factors affecting rice yield and nitrogen use efficiency in Jiangsu Province. Data from farm surveys conducted from 2008 to 2014.

\begin{tabular}{|c|c|c|c|c|c|c|c|c|}
\hline \multirow{2}{*}{$\begin{array}{l}\text { Farmers' } \\
\text { Production } \\
\text { Level }^{\text {a }}\end{array}$} & \multicolumn{4}{|c|}{ Limiting Factors-Nutrient Applications } & \multicolumn{4}{|c|}{$\begin{array}{l}\text { Limiting Factors-Farm and Farmer } \\
\text { Characteristics }\end{array}$} \\
\hline & $\begin{array}{c}\mathrm{N} \\
\left(\mathrm{kg} \mathrm{ha}^{-1}\right)\end{array}$ & $\begin{array}{c}\mathrm{P}_{2} \mathrm{O}_{5} \\
\left(\mathrm{~kg} \mathrm{ha}^{-1}\right)\end{array}$ & $\begin{array}{c}\mathrm{K}_{2} \mathrm{O} \\
\left(\mathrm{kg} \mathrm{ha}^{-1}\right)\end{array}$ & $\begin{array}{l}\text { Sample } \\
\text { Size (n) }\end{array}$ & $\begin{array}{l}\text { Area b } \\
\text { (ha) }\end{array}$ & $\begin{array}{l}\text { Age }{ }^{c} \\
\text { (year) }\end{array}$ & $\begin{array}{l}\text { Education } \\
\text { Level }^{d}\end{array}$ & $\begin{array}{l}\text { Sample } \\
\text { Size }^{\mathrm{e}}(\mathrm{n})\end{array}$ \\
\hline HYHE & $286 c$ & $77.2 \mathrm{a}$ & $75.6 a$ & 348 & $0.31 \mathrm{ab}$ & $49 \mathrm{~b}$ & $3.3 \mathrm{a}$ & 95 \\
\hline LYHE & $289 c$ & $80.3 a$ & $74.4 \mathrm{a}$ & 460 & $0.36 \mathrm{a}$ & $50 \mathrm{~b}$ & $3.0 \mathrm{~b}$ & 221 \\
\hline HYLE & $432 b$ & $81.1 \mathrm{a}$ & $75.4 a$ & 286 & $0.30 \mathrm{~b}$ & $48 \mathrm{~b}$ & $3.4 \mathrm{a}$ & 72 \\
\hline LYLE & $446 a$ & $83.2 \mathrm{a}$ & $67.8 b$ & 411 & $0.30 \mathrm{~b}$ & $55 a$ & $2.8 \mathrm{~b}$ & 195 \\
\hline Average & 358 & 80.6 & 73.0 & 1505 & 0.33 & 51 & 3.0 & 583 \\
\hline
\end{tabular}

${ }^{a}$ HYHE, LYHE, HYLE and LYLE represent high yield and high $\mathrm{N}$ use efficiency (NUE), low yield and high NUE, high yield and low NUE, and low yield and low NUE, respectively. ${ }^{b}$ The rice planting area presented in the table is for each family. ${ }^{c}$ and ${ }^{\mathrm{d}}$ Age and education level of the main labor force engaged in agriculture in each family are presented. The classification standard of farmers' education level is based on the following method: Level 1, uneducated with 0 years of education; Level 2, primary school incomplete with 1-6 years of education; Level 3, primary school completed with 6 years of education; Level 4, middle school with 6-9 years of education; Level 5, high school with 9-12 years of education; Level 6, higher education with more than 12 years of education. e It was challenging to collect data on education level, age of the major workforce and planting area given the personal nature of this information. To ensure completeness, only 583 questionnaires were used to analyze these characteristics. Different letters following the values in the same column indicate a statistically significant difference between different types of farmers at $p<0.05$ level.

Some studies have reported that yield potential and productivity are significantly related to labor force, the age of household head, education level and knowledge delivery to farmers [12,73]. Zhang et al. [25] reported farmers' non-optimal $\mathrm{N}$ management is a result of a lack of knowledge, and only $6.7 \%$ farmers could correctly calculate crop nutrient requirement. Along with the urbanization process, a large number of young or educated people have migrated to cities engaging in non-agricultural labor for a high income. As a result, the main agricultural labor force amongst smallholder rice farmers has become the elderly and poorly educated [74]. In our study, the average age of farmers approached 51 years old. $71 \%$ of farmers surveyed had no education or only primary school level. Furthermore, LYLE farmers were the oldest and the least educated of any farmer type (Table 4). These results indicate that ageing and poorly-educated farmers attain lower rice yields and $\mathrm{PFP}_{\mathrm{N}}$ compared to young and well-educated farmers, although low yields were also reported amongst educated farmers (Table S3). Huang et al. [75] reported that $\mathrm{N}$ fertilizer rate could be reduced by $20-30 \%$ through training and scientist-guided on-farm experiments without compromising rice yield. In contrast, although farmers in India are near- $100 \%$ literate, highly educated and informed, agronomy practice didn't improve with increased education, and rice yield was stagnating at low levels (only $2.5 \mathrm{t} \mathrm{ha}^{-1}$ ) [76,77]. Therefore, while education and access to appropriate knowledge are important, their effectiveness in increasing agronomy adoption by the average developing country farmer is not evident [12]. Centralized and mechanized land management are the main strategies to cope with the aging and low level of technology [72].

There are many biotic and abiotic factors including anthropogenic and natural factors, such as mechanization, variety, irrigation, soil and climate that interact to limit yields and NUE [24,78]. Further understanding of the causes of yield and NUE gaps and constraints on their improvement would require much more precise information on these limitations at different research scales.

\section{Conclusions}

Present regional-scale analysis revealed the large yield gaps between farmers' and potential yield across farmer types because of the poor agronomic practices, resulting in low NUE. Optimizing $\mathrm{N}$ management could narrow $\mathrm{YGs}$ and $\mathrm{PFP}_{\mathrm{N}}$ gaps among farmer' types. Our results highlight the potential of optimal N management to improve rice productivity and NUE. Multiple factors, including unbalanced fertilizer applications, small farm size, and aging and poorly educated workforce, 
could directly or indirectly limit farmers' ability to close rice YGs and increase NUE. It is important to extend technology to farmers, who are key to a more productive, profitable and environmentally sustainable crop management practices. Future work will require a multidisciplinary approach that involves not just science and technology, but also social and economic factors.

Supplementary Materials: The following are available online at http://www.mdpi.com/2073-4395/10/3/419/s1, Table S1: The number of samples from farm surveys and published studies used in this study. Table S2: Average grain yield, partial factor productivity of applied $\mathrm{N}\left(\mathrm{PFP}_{\mathrm{N}}\right)$ and nitrogen $(\mathrm{N})$, phosphorus $\left(\mathrm{P}_{2} \mathrm{O}_{5}\right)$ and potassium $\left(\mathrm{K}_{2} \mathrm{O}\right)$ application rates from farmer surveys conducted from 2008 to 2014 in Jiangsu province. Table S3: Household and plot characteristics of farmers in Jiangsu province surveyed from 2008 to 2014.

Author Contributions: Conceptualization, K.X. and J.G.; Methodology, K.X. and J.G.; Software, K.X.; Formal Analysis, K.X., J.G. and S.G.; Investigation, K.X.; Data Curation, K.X., J.G. and S.G.; Writing-Original Draft Preparation, K.X.; Writing-Review \& Editing, K.W., G.L. and S.G.; Project Administration, Q.S. and S.G. All authors have read and agreed to the published version of the manuscript.

Funding: This work was supported by the National Key Research and Development Program of China (2017YFD0200206), and the Special Fund for Agro-scientific Research in the Public Interest (20150312205).

Conflicts of Interest: The authors declare no conflict of interest.

\section{References}

1. FAO, Statistics Database. Available online: http://faostat.fao.org (accessed on 10 February 2020).

2. Peng, S.; Tang, Q.; Zou, Y. Current status and challenges of rice production in China. Plant Prod. Sci. 2009, 12, 3-8. [CrossRef]

3. Zhang, J. China's success in increasing per capita food production. J. Exp. Bot. 2011, 62, 3707-3711. [CrossRef]

4. Lobell, D.B.; Cassman, K.G.; Field, C.B. Crop yield gaps: Their importance, magnitudes, and causes. Annu. Rev. Environ. Resour. 2009, 34, 179-204. [CrossRef]

5. Godfray, H.C.J.; Beddington, J.R.; Crute, I.R.; Haddad, L.; Lawrence, D.; Muir, J.F.; Pretty, J.; Robinson, S.; Thomas, S.M.; Toulmin, C. Food security: The challenge of feeding 9 billion people. Science 2010, 327, 812-818. [CrossRef] [PubMed]

6. Zhang, H.; Tao, F.; Zhou, G. Potential yields, yield gaps, and optimal agronomic management practices for rice production systems in different regions of China. Agric. syst. 2019, 171, 100-112. [CrossRef]

7. Chen, X.; Cui, Z.; Fan, M.; Vitousek, P.; Zhao, M.; Ma, W.; Wang, Z.; Zhang, W.; Yan, X.; Yang, J. Producing more grain with lower environmental costs. Nature 2014, 514, 486-489. [CrossRef] [PubMed]

8. Keating, B.A.; Carberry, P.S.; Bindraban, P.S.; Asseng, S.; Meinke, H.; Dixon, J. Eco-efficient agriculture: Concepts, challenges, and opportunities. Crop Sci. 2010, 50, S-109-S-119. [CrossRef]

9. Guilpart, N.; Grassini, P.; Sadras, V.O.; Timsina, J.; Cassman, K.G. Estimating yield gaps at the cropping system level. Field Crop. Res. 2017, 206, 21-32. [CrossRef]

10. Mills, G.; Sharps, K.; Simpson, D.; Pleijel, H.; Frei, M.; Burkey, K.; Emberson, L.; Uddling, J.; Broberg, M.; Feng, Z.; et al. Closing the global ozone yield gap: Quantification and cobenefits for multistress tolerance. Glob. Chang. Biol. 2018, 24, 4869-4893. [CrossRef]

11. West, P.C.; Gerber, J.S.; Engstrom, P.M.; Mueller, N.D.; Brauman, K.A.; Carlson, K.M.; Cassidy, E.S.; Johnston, M.; MacDonald, G.K.; Ray, D.K. Leverage points for improving global food security and the environment. Science 2014, 345, 325-328. [CrossRef]

12. George, T. Why crop yields in developing countries have not kept pace with advances in agronomy. Glob. Food Secur. Agric. Policy 2014, 3, 49-58. [CrossRef]

13. Pampolino, M.F.; Manguiat, I.J.; Ramanathan, S.; Gines, H.C.; Tan, P.S.; Chi, T.T.N.; Rajendran, R.; Buresh, R.J. Environmental impact and economic benefits of site-specific nutrient management (SSNM) in irrigated rice systems. Agric. Syst. 2007, 93, 1-24. [CrossRef]

14. Zhang, W.; Dou, Z.; He, P.; Ju, X.; Powlson, D.; Chadwick, D.; Norse, D.; Lu, Y.; Zhang, Y.; Wu, L.; et al. New technologies reduce greenhouse gas emissions from nitrogenous fertilizer in China. Proc. Natl. Acad. Sci. USA 2013, 110, 8375. [CrossRef] [PubMed]

15. Robertson, M.J.; Lyle, G.; Bowden, J.W. Within-field variability of wheat yield and economic implications for spatially variable nutrient management. Field Crop. Res. 2008, 105, 211-220. [CrossRef] 
16. Guo, J.; Liu, X.; Zhang, Y.; Shen, J.; Han, W.; Zhang, W.; Christie, P.; Goulding, K.W.T.; Vitousek, P.; Zhang, F. Significant acidification in major Chinese croplands. Science 2010, 327, 1008-1010. [CrossRef]

17. Sayer, J.; Cassman, K.G. Agricultural innovation to protect the environment. Proc. Natl. Acad. Sci. USA 2013, 110, 8345-8348. [CrossRef]

18. Fan, M.; Shen, J.; Yuan, L.; Jiang, R.; Chen, X.; Davies, W.J.; Zhang, F. Improving crop productivity and resource use efficiency to ensure food security and environmental quality in China. J. Exp. Bot. 2012, 63, 13-24. [CrossRef]

19. An, N.; Wei, W.; Qiao, L.; Zhang, F.; Christie, P.; Jiang, R.; Dobermann, A.; Goulding, K.W.T.; Fan, J.; Fan, M. Agronomic and environmental causes of yield and nitrogen use efficiency gaps in Chinese rice farming systems. Eur. J. Agron. 2018, 93, 40-49. [CrossRef]

20. Cassman, K.G.; Dobermann, A.; Walters, D.T.; Yang, H. Meeting cereal demand while protecting natural resources and improving environmental quality. Annu. Rev. Environ. Resour. 2003, 28, 315-358. [CrossRef]

21. Zhang, X.; Davidson, E.A.; Mauzerall, D.L.; Searchinger, T.D.; Dumas, P.; Shen, Y. Managing nitrogen for sustainable development. Nature 2015, 528, 51. [CrossRef]

22. Mueller, N.D.; Gerber, J.S.; Johnston, M.; Ray, D.K.; Ramankutty, N.; Foley, J.A. Closing yield gaps through nutrient and water management. Nature 2012, 490, 254. [CrossRef] [PubMed]

23. An, N.; Fan, M.; Zhang, F.; Christie, P.; Yang, J.; Huang, J.; Guo, S.; Shi, X.; Tang, Q.; Peng, J. Exploiting co-benefits of increased rice production and peduced greenhouse gas emission through optimized crop and soil management. PLoS ONE 2015, 10, e0140023. [CrossRef] [PubMed]

24. Affholder, F.; Poeydebat, C.; Corbeels, M.; Scopel, E.; Tittonell, P. The yield gap of major food crops in family agriculture in the tropics: Assessment and analysis through field surveys and modelling. Field Crop. Res. 2013, 143, 106-118. [CrossRef]

25. Zhang, W.; Cao, G.; Li, X.; Zhang, H.; Wang, C.; Liu, Q.; Chen, X.; Cui, Z.; Shen, J.; Jiang, R.; et al. Closing yield gaps in China by empowering smallholder farmers. Nature 2016, 537, 671-674. [CrossRef] [PubMed]

26. Ding, W.; Xu, X.; He, P.; Ullah, S.; Zhang, J.; Cui, Z.; Zhou, W. Improving yield and nitrogen use efficiency through alternative fertilization options for rice in China: A meta-analysis. Field Crop. Res. 2018, 227, 11-18. [CrossRef]

27. Linquist, B.A.; Liu, L.; Kessel, C.V.; Groenigen, K.J.V. Enhanced efficiency nitrogen fertilizers for rice systems: Meta-analysis of yield and nitrogen uptake. Field Crop. Res. 2013, 154, 246-254. [CrossRef]

28. Peng, S.; Buresh, R.J.; Huang, J.; Zhong, X.; Zou, Y.; Yang, J.; Wang, G.; Liu, Y.; Hu, R.; Tang, Q. Improving nitrogen fertilization in rice by site-specific N management. A review. Agron. Sustain. Dev. 2010, 30, 649-656. [CrossRef]

29. Xu, X.; He, P.; Zhao, S.; Qiu, S.; Johnston, A.M.; Zhou, W. Quantification of yield gap and nutrient use efficiency of irrigated rice in China. Field Crop. Res. 2016, 186, 58-65. [CrossRef]

30. Nhamo, N.; Rodenburg, J.; Zenna, N.; Makombe, G.; Luzi-Kihupi, A. Narrowing the rice yield gap in East and Southern Africa: Using and adapting existing technologies. Agric. Syst. 2014, 131, 45-55. [CrossRef]

31. Dobermann, A.; Witt, C.; Dawe, D.; Abdulrachman, S.; Gines, H.C.; Nagarajan, R.; Satawathananont, S.; Son, T.T.; Tan, P.S.; Wang, G.H. Site-specific nutrient management for intensive rice cropping systems in Asia. Field Crop. Res. 2002, 74, 37-66. [CrossRef]

32. Lassaletta, L.; Billen, G.; Garnier, J.; Bouwman, L.; Velazquez, E.; Mueller, N.D.; Gerber, J.S. Nitrogen use in the global food system: Past trends and future trajectories of agronomic performance, pollution, trade, and dietary demand. Environ. Res. Lett. 2016, 11, 095007. [CrossRef]

33. NBSC, National Bureau of Statistics of China. China Statistical Yearbook 2015; Statistical Press: Beijing, China, 2015.

34. Guo, J.; Hu, X.; Gao, L.; Xie, K.; Ling, N.; Shen, Q.; Hu, S.; Guo, S. The rice production practices of high yield and high nitrogen use efficiency in Jiangsu, China. Sci Rep. 2017, 7, 2101. [CrossRef] [PubMed]

35. Cui, Z.; Zhang, H.; Chen, X.; Zhang, C.; Ma, W.; Huang, C.; Zhang, W.; Mi, G.; Miao, Y.; Li, X.; et al. Pursuing sustainable productivity with millions of smallholder farmers. Nature 2018, 555, 363. [CrossRef] [PubMed]

36. Gong, J.; Zhang, H.; Li, J.; Dai, Q.G.; Huo, Z.Y.; Xu, k.; Li, D.; Hua, Z.; Sha, A.; Zhou, Y.; et al. Progress in research on patterns and systematic theories of super-high-yielding cultivation in rice. Chin. J. Rice Sci. 2010, $24,417-424$. 
37. Chen, G.; Gao, J.; Zhao, M.; Dong, S.; Li, S.; Yang, Q.; Liu, Y.; Wang, L.; Xue, J.; Liu, J. Distribution, yield structure, and key cultural techniques of maize super-high yield plots in recent years. Acta Agron. Sinica 2013, 38, 80-85. [CrossRef]

38. Hu, Y.; Cao, W.; Qian, H.; Xing, Z.; Zhang, H.; Dai, Q.; Huo, Z.; Xu, K.; Wei, H.; Guo, B. Effect of planting density of mechanically transplanted pot seedlings on yield, plant type and lodging resistance in rice with different panicle types. Acta Agron. Sinica 2015, 41, 743. [CrossRef]

39. Tittonell, P.; Vanlauwe, B.; Corbeels, M.; Giller, K.E. Yield gaps, nutrient use efficiencies and response to fertilisers by maize across heterogeneous smallholder farms of western Kenya. Plant. Soil 2008, 313, 19-37. [CrossRef]

40. Liang, W.; Carberry, P.; Wang, G.; Lü, R.; Lü, H.; Xia, A. Quantifying the yield gap in wheat-maize cropping systems of the Hebei Plain, China. Field Crop. Res. 2011, 124, 180-185. [CrossRef]

41. Meng, Q.; Hou, P.; Wu, L.; Chen, X.; Cui, Z.; Zhang, F. Understanding production potentials and yield gaps in intensive maize production in China. Field Crop. Res. 2013, 143, 91-97. [CrossRef]

42. Gu, J.; Chen, Y.; Zhang, H.; Li, Z.; Zhou, Q.; Yu, C.; Kong, X.; Liu, L.; Wang, Z.; Yang, J. Canopy light and nitrogen distributions are related to grain yield and nitrogen use efficiency in rice. Field Crop. Res. 2017, 206, 74-85. [CrossRef]

43. Liu, B.; Chen, X.; Cui, Z.; Meng, Q.; Zhao, M. Research advance in yield potential and yield gap of three major cereal crops. Chin. J. Eco-Agric. 2015, 23, 525-534.

44. Cassman, K.G.; Dobermann, A.; Walters, D.T. Agroecosystems, nitrogen-use Efficiency, and nitrogen management. Ambio 2002, 31, 132. [CrossRef] [PubMed]

45. Fageria, N.K.; Baligar, V.C. Enhancing nitrogen use efficiency in crop plants. Adv. Agron. 2005, 88, 97-185.

46. Cassman, K.G.; Gines, G.C.; Dizon, M.A.; Samson, M.I.; Alcantara, J.M. Nitrogen-use efficiency in tropical lowland rice systems: Contributions from indigenous and applied nitrogen. Field Crop. Res. 1996, 47, 1-12. [CrossRef]

47. van Noordwijk, M.; Brussaard, L. Minimizing the ecological footprint of food: Closing yield and efficiency gaps simultaneously? Curr. Opin. Environ. Sustain. 2014, 8, 62-70. [CrossRef]

48. Grassini, P.; Eskridge, K.M.; Cassman, K.G. Distinguishing between yield advances and yield plateaus in historical crop production trends. Nat. Commun. 2013, 4, 2918. [CrossRef]

49. Fan, M.; Lu, S.; Jiang, R.; Liu, X.; Zhang, F. Triangular transplanting pattern and split nitrogen fertilizer application increase rice yield and nitrogen fertilizer recovery. Agron. J. 2009, 101, 1421-1425. [CrossRef]

50. Ju, X.T.; Xing, G.X.; Chen, X.P.; Zhang, S.L.; Zhang, L.J.; Liu, X.J.; Cui, Z.L.; Yin, B.; Christie, P.; Zhu, Z.L. Reducing environmental risk by improving $\mathrm{N}$ management in intensive Chinese agricultural systems. Proc. Natl. Acad. Sci. USA 2009, 106, 3041-3046. [CrossRef]

51. Miao, Y.; Stewart, B.A.; Zhang, F. Long-term experiments for sustainable nutrient management in China. A review. Agron. Sustain. Dev. 2011, 31, 397-414. [CrossRef]

52. Dobermann, A.; Fairhurst, T.H. Rice: Nutrient Disorders and Nutrient Management; Potash and Phosphate Institute: Singapore; IRRI: Manila, Philippines, 2000.

53. Dobermann, A.; Krauss, A.; Isherwood, K.; Heffer, P. Nutrient use efficiencymeasurement and management. In Fertilizer Best Management Practices. General Principles, Strategy for Their Adoption and Voluntary Initiatives vs. Regulations, IFA International Workshop on Fertilizer Best Management Practices, Brussels, Belgium, 7-9 March 2007; International Fertilizer Industry Association (IFA): Paris, France, 2007; pp. 1-28.

54. Laborte, A.G.; de Bie, K.; Smaling, E.M.A.; Moya, P.F.; Boling, A.A.; Van Ittersum, M.K. Rice yields and yield gaps in Southeast Asia: Past trends and future outlook. Eur. J. Agron. 2012, 36, 9-20. [CrossRef]

55. van Ittersum, M.K.; Cassman, K.G.; Grassini, P.; Wolf, J.; Tittonell, P.; Hochman, Z. Yield gap analysis with local to global relevance-A review. Field Crops Res. 2013, 143, 4-17. [CrossRef]

56. Fan, M.; Lu, S.; Jiang, R.; Liu, X.; Zeng, X.; Goulding, K.W.T.; Zhang, F. Nitrogen input, ${ }^{15} \mathrm{~N}$ balance and mineral $\mathrm{N}$ dynamics in a rice-wheat rotation in southwest China. Nutr. Cycl. Agroecosyst. 2007, 79, $255-265$. [CrossRef]

57. Xue, L.; Yu, Y.; Yang, L. Maintaining yields and reducing nitrogen loss in rice-wheat rotation system in Taihu Lake region with proper fertilizer management. Environ. Res. Lett. 2014, 9, 115010. [CrossRef]

58. Xia, L.; Xia, Y.; Li, B.; Wang, J.; Wang, S.; Zhou, W.; Yan, X. Integrating agronomic practices to reduce greenhouse gas emissions while increasing the economic return in a rice-based cropping system. Agric. Ecosyst. Environ. 2016, 231, 24-33. [CrossRef] 
59. Zhang, M.; Yao, Y.; Zhao, M.; Zhang, B.; Tian, Y.; Yin, B.; Zhu, Z. Integration of urea deep placement and organic addition for improving yield and soil properties and decreasing $\mathrm{N}$ loss in paddy field. Agric. Ecosyst. Environ. 2017, 247, 236-245. [CrossRef]

60. Yang, Y.; Zhang, M.; Li, Y.C.; Fan, X.; Geng, Y. Controlled release urea improved nitrogen use efficiency, activities of leaf enzymes, and rice yield. Soil Sci. Soc. Am. J. 2012, 76, 2307-2317. [CrossRef]

61. Wilkinson, S.; Bacon, M.A.; Davies, W.J. Nitrate signalling to stomata and growing leaves: Interactions with soil drying, ABA, and xylem sap pH in maize. J. Exp. Bot. 2007, 58, 1705. [CrossRef]

62. Fan, M.; Cui, Z.; Chen, X.; Jiang, R.; Zhang, F. Integrated nutrient management for improving crop yields and nutrient utilization efficiencies in China. J. Soil Water Conserv. 2008, 63, 126-128. [CrossRef]

63. Hati, K.M.; Mandal, K.G.; Misra, A.K.; Ghosh, P.K.; Bandyopadhyay, K.K. Effect of inorganic fertilizer and farmyard manure on soil physical properties, root distribution, and water-use efficiency of soybean in Vertisols of central India. Bioresour. Technol. 2006, 97, 2182-2188. [CrossRef]

64. Azadi, H.; Schoonbeek, S.; Mahmoudi, H.; Derudder, B.; Maeyer, P.D.; Witlox, F. Organic agriculture and sustainable food production system: Main potentials. Agric. Ecosyst. Environ. 2011, 144, 92-94. [CrossRef]

65. Xia, L.; Lam, S.K.; Yan, X.; Chen, D. How does recycling of livestock manure in agroecosystems affect crop productivity, reactive nitrogen losses and soil carbon balance? Environ. Sci. Technol. 2017, 51, 7450. [CrossRef] [PubMed]

66. Xia, L.; Shu, K.L.; Chen, D.; Wang, J.; Quan, T.; Yan, X. Can knowledge-based N management produce more staple grain with lower greenhouse gas emission and reactive nitrogen pollution? A meta-analysis. Global Change Biol. 2017, 23, 1917-1925. [CrossRef]

67. Zhang, F.; Chen, X.; Chen, Q. Guidelines for fertilization of major crops in China; China Agricultural Press: Beijing, China, 2009.

68. Zhen, L.; Zoebisch, M.A.; Chen, G.; Feng, Z. Sustainability of farmers' soil fertility management practices: A case study in the North China Plain. J. Environ. Manag. 2006, 79, 409-419. [CrossRef]

69. Ju, X.; Gu, B.; Wu, Y.; Galloway, J.N. Reducing China's fertilizer use by increasing farm size. Global Environ. Chang. 2016, 41, 26-32. [CrossRef]

70. CSAC, The Office of China's Second Agricultural Census. Compilation of China's Second Agricultural Census; China Statistics Press: Beijing, China, 2009.

71. Foster, A.D.; Rosenzweig, M.R. Are there too many farms in the world? Labor-market transaction costs, machine capacities and optimal farm size. Soc. Sci. Electron. Publ. 2017.

72. Wu, Y.; Xi, X.; Tang, X.; Luo, D.; Gu, B.; Lam, S.K.; Vitousek, P.M.; Chen, D. Policy distortions, farm size, and the overuse of agricultural chemicals in China. Proc. Natl. Acad. Sci. USA 2018, 115, 7010. [CrossRef] [PubMed]

73. Cao, R. Empirical study on the factors influencing rape framers' adoption of new variety. Econom. Perspect. 2011, 8, 146-147.

74. Zhou, J.H.; Tang, L.Q.; Yu, X. Estimating the average treatment effect of adopting stress tolerant variety on rice yield in China. J. Integr. Agric. 2018, 17, 940-948. [CrossRef]

75. Huang, J.; Huang, Z.; Jia, X.; Hu, R.; Xiang, C. Long-term reduction of nitrogen fertilizer use through knowledge training in rice production in China. Agric. Syst. 2015, 135, 105-111. [CrossRef]

76. Government of India. Literates and literacy Rate, Primary Census Data Highlights; Census of India: New Delhi, India, 2011; pp. 45-55.

77. Government of Kerala. Agriculture and Allied Sectors, Economic Review, State Planning Board; Trivandrum, India, 2010.

78. Wang, X.; Li, T.; Yang, X.; Zhang, T.; Liu, Z.; Guo, E.; Liu, Z.; Qu, H.; Chen, X.; Wang, L.; et al. Rice yield potential, gaps and constraints during the past three decades in a climate-changing Northeast China. Agric. For. Meteorol. 2018, 259, 173-183. [CrossRef]

(C) 2020 by the authors. Licensee MDPI, Basel, Switzerland. This article is an open access article distributed under the terms and conditions of the Creative Commons Attribution (CC BY) license (http://creativecommons.org/licenses/by/4.0/). 